\title{
Shades of green: Centralisation, decentralisation and controversy among European renewable electricity visions
}

\author{
Johan Lilliestam ${ }^{\mathrm{a}, *}$, Susanne Hanger ${ }^{\mathrm{a}, \mathrm{b}}$ \\ a ETH Zürich, Institute for Environmental Decisions, Climate Policy Group, Universitätstrasse 22, CHN J71, 8092 Zürich, Switzerland \\ ${ }^{\mathrm{b}}$ International Institute for Applied Systems Analysis (IIASA), Risk, Policy and Vulnerability Program, Schlossplatz 1, 2361 Laxenburg, Austria
}

\begin{abstract}
A B S T R A C T
To decarbonise its electricity system, Europe must rapidly expand renewables. We analyse the controversy between two organisations, Eurosolar and Desertec, which seemingly pursue the same goal of $100 \%$ renewable electricity. We show that they interpret " $100 \%$ renewables" differently and envision fundamentally different renewable electricity futures, to be reached through different governance pathways driven by different actors. Desertec reacts to mankind's violation of the Earth's carrying capacity and seeks secure decarbonisation through renewables, for which centrally regulated, large-scale imports of controllable concentrating solar power from the desert are necessary. Eurosolar, in contrast, seeks to decentralise the electricity supply and disempower the actors who caused the unsustainable and undemocratic energy system, for which renewables are suited as they are carbon-neutral and decentralised by nature. As the core aim of Desertec, controllable solar power imports through large-scale infrastructure, violates Eurosolar's core aim of decentralisation, a compromise is difficult: this would require one organisation to give up its primary objective. Our results show that the reason for this controversy among renewables proponents lies not in technology or cost, and can thus not be identified or resolved through techno-economic analysis or modelling, but in irreconcilable differences in normative aims and governance choices.
\end{abstract}

\section{Introduction}

To reach the long-term climate targets, the European electricity sector must be completely decarbonised by mid-century [1-4]. On the supply side, different combinations of nuclear power, fossil power with CCS, and renewables can achieve this [5] and there are intense political debates which of these is the best. Perhaps the least surprising debate is between proponents of conventional electricity technologies - nuclear power or fossil fuels (with/without CCS) - and renewables: creating a new, renewable electricity system will trigger resistance from those with interests in the old system, and there are strong ideological differences between a nuclear- and a renewables-based future. In some countries, notably Germany, the nuclear issue is among the most heated political conflicts of all and a historical starting point for the political environmentalist movements, and the nuclear-renewables conflict is still a main driver of the energy debate [6].

\footnotetext{
* Corresponding author.

E-mail address: johan.lilliestam@usys.ethz.ch (J. Lilliestam).
}

Visions are emotionally appealing descriptions of the problem to solve, the desired future system and the policies and governance pathways to achieve that future [7-9]. Hence, visions for nuclear/fossil energy or renewables may be very different, and, as we show in this article, also renewables visions may differ greatly. In order to remain "objective", however, mainstream energy system modellers are careful to "distinguish their 'visions' from their calculations" [10] and consider techno-economic features in detail while ignoring, explicitly or implicitly, most governance choices and normative aspects of the energy system [11]. Modern energy scenarios describe how broader societal or political developments affect the energy future [12,13] (e.g. regional rivalry or more global cooperation [14]). The policy recommendations are however often "presented in singular prescriptive ways", and policy-makers often refer to techno-economic energy studies for "proof" that their proposal is, in fact, the best [15].

Yet, renewables differ from conventional power in more respects than their carbon-neutrality. Importantly, they are modular and can be built as rooftop PV arrays or single wind turbines, or in gigawatt-sized farms. Hence, both small, including individual citizens, and large investors such as major energy companies can build and own renewable power stations, with far-reaching differ- 
ences both in impacts (e.g. cost, whether value-creation is localised or remote) and in the governance pathways (e.g. feed-in tariffs enabling small-scale investors, or quota schemes with higher risk favouring large companies) [4,11]. The technical characteristics of renewables add a societal dimension, suggesting that renewables may not be simply technologies but that they may also entail a societal, normative - and hence potentially conflict-laden - choice of which type of renewable electricity future is most desirable [16].

One controversy among renewables proponents has been ongoing since the early 2000s between the organisations Desertec Foundation and Eurosolar. This is intriguing, as the two organisations appear to have the same aim. Eurosolar is dedicated to "completely substituting fossil and nuclear energy through renewable energy", which they view as "the challenge of the century to humanity" [17], and Desertec propagates the replacement of nuclear and fossil power with renewables to avoid risks "of nuclear proliferation and of climate change" [18], which "confront mankind with unprecedented challenges" [19].

Still, Eurosolar is among the harshest critics of Desertec, which it perceives as "a mirage"i [20], "a step backwards to the conceptual clutter of the early 20th century"ii [21], and a "pseudo-progressive [and] tedious detour"iii [22]. Rather than a vision for a renewable future, Desertec is "a political weapon against the expansion of local and regional solar and wind power"iv [22]. Desertec, in contrast, sees Eurosolar's strategy as "questionable in terms of ethics and sustainability [as it] propagates a Europe unaffected by the eventual future misery of its neighbours, and fosters the illusion of independency on a rather small and crowded planet"; further, Eurosolar's one-sided focus on local and small-scale renewables makes the transition insecure and slow [23]. Instead of rejecting Eurosolar's vision altogether, however, Desertec states that "decentralized and internationally linked renewable energy resources optimally complement each other": given the urgency of the climate and energy crises, we need both [24].

Here, we investigate this apparent paradox and identify the reasons why Eurosolar and Desertec disagree so strongly although they seemingly want the same thing. We seek the reason of the controversy, despite the apparent agreement on $100 \%$ renewables, in differences in their visions: what do these organisations want, and how are their visions different? Ultimately, the question arises: are the two visions mutually exclusive, because their core aims clash, or is a compromise possible? We hypothesise that they, behind the headline rhetoric, strive to achieve fundamentally different and incompatible renewable energy futures, through largely diverging governance approaches: we expect that this energy controversy is not primarily about the power mixes, the pie-charts or the costs of the different futures, but about the softer issues such as how the envisioned system and the transition are governed, which problem each vision aims to solve, and who carries out the transition. In short: we expect that the controversy we investigate is rooted in fundamental differences in the visions. By empirically exploring the visions of two organisations in the German renewables policy arena, we seek to convey to scientific electricity system modelling and the energy policy debate that there is a "plurality of social interpretations of energy alternatives, each equally valid under different reasonable perspectives" [15].

Below, we review the literature and reflect on how visions may be classified in a number of different but similar theoretical predictions of vision type taxonomies (Section 2). Inspired by discourse analysis, our method is centred on the concept of storylines, which allow us to efficiently summarise the main arguments of the two visions (Section 3). We describe the organisations and their political impact (Sections 4.1 and 4.3), and identify (Sections 4.2 and 4.4) and compare (Section 4.5) their storylines. In Section 5, we discuss our findings and present conclusions.

\section{Background}

The mainstream energy system and energy policy research focuses on the technical and economic aspects of renewable energy scenarios [25-29]. Over the last decade, numerous studies have shown that high - up to $100 \%$ - shares of renewables are technically feasible and economically attractive in many countries and regions, including Australia [30], Denmark [31], Germany [32], the US [33], Europe [3,34], Europe and MENA (Middle East and North Africa) [35], and even globally [36]. Such techno-economic studies however tend to ignore or "mask the human elements of energy" [26], which calls for "the tool-box of social sciences" to be used to support and improve techno-economic system modelling [11].

Indeed, several social-scientific authors criticise the "disappointing" [37] scope of mainstream energy science, because "conflicts in the domain of energy and climate are not primarily due to lack of scientific facts or objective truth. Instead, they are more due to a clash of priorities, interests, and normative assumptions which create a number of subjective truths" [38]. Although visions are key drivers of the energy policy debate, they are largely ignored by the mainstream literature [7-9]. An energy vision does not address all problems in the world but merely a subset, reflecting the subjective perception and prioritisation of problems. As different persons value problems differently, the subset of problems to solve differs between visions, and the visions themselves can although they address the same physical reality - be fundamentally different. Hence, there is not one single techno-economic truth, but multiple socially constructed truths with different but valid endstate aims and governance pathways $[9,38]$ (see below). This is a key source of conflict, since "people are unlikely to support a policy that is aimed at solving what they do not see to be the problem" [39].

Authors have gone about classification of visions for electricity decarbonisation in different ways. Battaglini et al. [40], for example, identify two main options for $100 \%$ renewables in Europe: bottom-up, decentralised Smartgrid solutions focusing on smallscale generation, and top-down, centralised Supergrid approaches, focusing on very large transmission systems and large-scale generation. Yet, they argue that Europe has no time to quarrel about which type of renewables it wants, so that "the two concepts [...] can and must co-exist in order to guarantee a transition to a decarbonised economy" [40]: the two visions can and must be merged into a SuperSmart Grid vision. This is exactly the same statement as Desertec's reply to Eurosolar's criticism (see Section 1).

Others adopt the position that a transformation of the energy system is not mainly about energy as such, but about governance of the energy system [41-43]. Lovins, for example, distinguishes between Hard and Soft energy paths and characterises the essence of energy politics as a choice between these $[44,45]$. The Hard path focuses on ways to supply more energy to satisfy a growing demand in a centralised system based on technological progress. The centralised Hard path remains dominant, both in European energy policy [1] and in system modelling [11]. The Soft path, in contrast, emphasises demand-constraint combined with decentralisation of energy governance and puts energy generation directly under citizen ownership or control. These Paths are not mainly distinguished "by choices of hardware" but "by the socio-political structure of the energy system"; hence, they are technically compatible but "mutually exclusive" because of diverging governance requirements and aims [44].

In the Realising Transitions Pathways project [46,47], Foxon and colleagues define qualitative decarbonisation visions for the UK and then quantify these into vision-driven "transition pathways". Instead of using the standard approach of modelling a cost-optimal decarbonised technical electricity system without asking about governance choices and system structure, they place 
normative end-state aims and governance pathways as the starting point and build quantitative scenarios from that. Based on the Multi-level Perspective on Sociotechnical Transitions (MLP) $[48,49]$, this project suggests that there are three competing Logics in UK low-carbon energy policy and energy research - the Market, Government and Civil Society Logics - each with a distinct dominant actor, governance path and end-state decarbonisation aim $[46,47]$. In the Market logic, energy firms are the dominant actors, whereas policy-makers should "set the framework and get out". This leaves the market as the principal coordination mechanism for decarbonisation, leading to large generation assets and a strong transmission system. In the Government Logic, the government directly manages the transition to a decarbonised future, through a government agency issuing contracts for tranches of low-carbon supply, leading to a similar infrastructure system as in the Market Logic. In the Civil Society Logic, the government enables the transition through a feed-in tariff and the transition happens through a multitude of bottom-up, local community approaches driven by citizens, local entrepreneurs and social movements, leading to more decentralised supply and a stronger focus on distribution than transmission. The choice of which logic is the best and should dominate national energy policy is "inherently political" and cannot be modelled but must follow from a "debate on what kind of energy future we, as a society, would like to see" [47].

The three competing Logics are similar, but not identical, to the assertions made by Cultural Theory [50] (CT; see Ref. [51] for a discussion of how MLP and CT fit together). Rooted in anthropology, CT claims that in every policy debate, there are four fundamental, mutually exclusive forms of Rationalities, each based on axioms regarding human nature and interactions that explain how people perceive the world. These Rationalities are determined by two social dimensions (see Fig. 1): the grid refers to the degree to which rules and outside authority determine individual behaviour, whereas the group refers to the degree to which the commitment to a group affects individual thought and action [52].

Loose grid and weak group cohesion determine an Individualistic Rationality. Individualists stand for high individual responsibility, independence and trust in the market and its efficiency for solving problems. Translated to the context of our study, individualists let all (renewable) technologies compete on a free market, letting the most competitive ones prevail, similar to Foxon's Market Logic. Featuring high grid and strong group cohesion is Hierarchism. Hierarchists prefer state control and regulation and turn to experts for guidance on problems and crises. Hierarchic electricity solutions are top-down, relying on large-scale solutions tightly controlled by policy; this is similar to Foxon's Government Logic. Egalitarianism is characterised by loose grid and strong group cohesion, so that egalitarians prefer communal, non-discriminating solutions. For the electricity sector, egalitarians seek communally owned, small-scale solutions matching local and regional capacity and needs, similarly to Foxon's Civil Society logic. Finally, dense grid but weak group cohesion qualifies as Fatalism, which is usually absent from policy debates. According to CT, working real world formations are rarely or never elegant - i.e. policies presented as without alternative, fully achieving the aims of only one Rationality - but are inevitably clumsy solutions that do not fulfil all wishes of any Rationality completely, but are a compromise between the three Rationalities and acceptable, or non-objectable, to all.

This theoretical literature suggests that there are fundamentally different renewable electricity visions and that diverging visions are a key reason for controversy. In the following sections, we empirically investigate the visions of Desertec and Eurosolar as expressed in their respective storylines to see whether and in which respects the visions differ, and whether a compromise seems possible or if their core aims clash, making them mutually exclusive.

\section{Method}

In order to answer our research questions and find out what the controversy between Eurosolar and Desertec is about and whether a compromise is possible, we must understand what these organisations see as the problem, what solution they aim for and how they want to achieve it, and whether there are fundamental differences in their aims or tools. Here, we do this by identifying and analysing their storylines, using key elements of discourse analysis.

A discourse is "a shared way of apprehending the world" [54], providing its adherents with concepts, categorisations and convictions about a particular phenomenon, giving meaning and legitimacy to associated knowledge [55]. Discourses shape what can and cannot be said and delimit both the problem framing and the range of policy options, and therefore serve as precursors to policy outcomes [56,57]. A discourse is manifested in storylines, metaphors and discourse coalitions, it is communicated through text and speech (e.g. books, reports, conferences) and can be identified by analysis of the same [55-58].

Storylines are "condensed statements summarizing complex narratives" that are "used as 'short hand"' in debates [58]. In this paper, we examine the storylines of the two organisations, as these provide brief and comprehensible summaries of their visions. Storylines, just like all stories, have "a beginning, a middle and an end" and they have specific elements, such as heroes, villains, a problem to solve, a complication or a twist, and a moral [58-60] (see below). Metaphors highlight and illustrate key concepts of a discourse and the mere mentioning of a metaphor may call into mind a whole narrative; the metaphor "climate change", for example, may re-invoke the narrative of a heating climate caused by humans without necessitating re-telling all scientific arguments [61]. Discourse coalitions are groups of actors subscribing to certain storylines and using them in an identifiable set of practices [55].

In our analysis, we focus on the storylines to reveal the different interpretations of the common metaphor " $100 \%$ renewables". As neither organisation can be said to represent a whole discourse coalition, although we believe that both are indeed dominant actors in their respective coalitions (see the policy impact descriptions in Sections 4.1 and 4.3), and as this is irrelevant to our research questions, we do not further use the discourse coalition concept: the storylines identified and analysed here are those of these two organisations only. We equally do not discuss which organisation is the most powerful or whether one story has achieved discursive hegemony: we focus only on identifying and comparing the visions of Desertec and Eurosolar as expressed in their storylines.

In order to reproducibly trace the storylines, we examine the main written outlets of the two groups. In this, we focus on publications from the last decade, and especially from 2008 onwards, capturing the time when both organisations were visible in the political debate (see organisation descriptions in Sections 4.1 and 4.3). We describe the Desertec storyline as expressed in the publications of TREC/Desertec Foundation, as well as by individuals and organisations belonging to the Desertec network. This includes all major publications of Desertec, including the widely distributed White book [18] and Red paper [19]. We describe the Eurosolar storyline as depicted in the books of Hermann Scheer, the founder and key thinker of Eurosolar, and all articles in its journal Solarzeitalter from 2005 onwards [62]. We use both English and German texts, and translate all German quotes ourselves.

We identify the storylines of Desertec and Eurosolar through analysis of the key storyline elements, both by means of elementby-element comparison and through the lenses of the theoretical taxonomies described in Section 2. We structure the storylines as inspired by Verweij et al. [59] and Fløttum and Gjerstad [60] (see also above) by the storyline elements, describing the heroes, i.e. the key actors carrying out the solution outlined in the storyline; the 


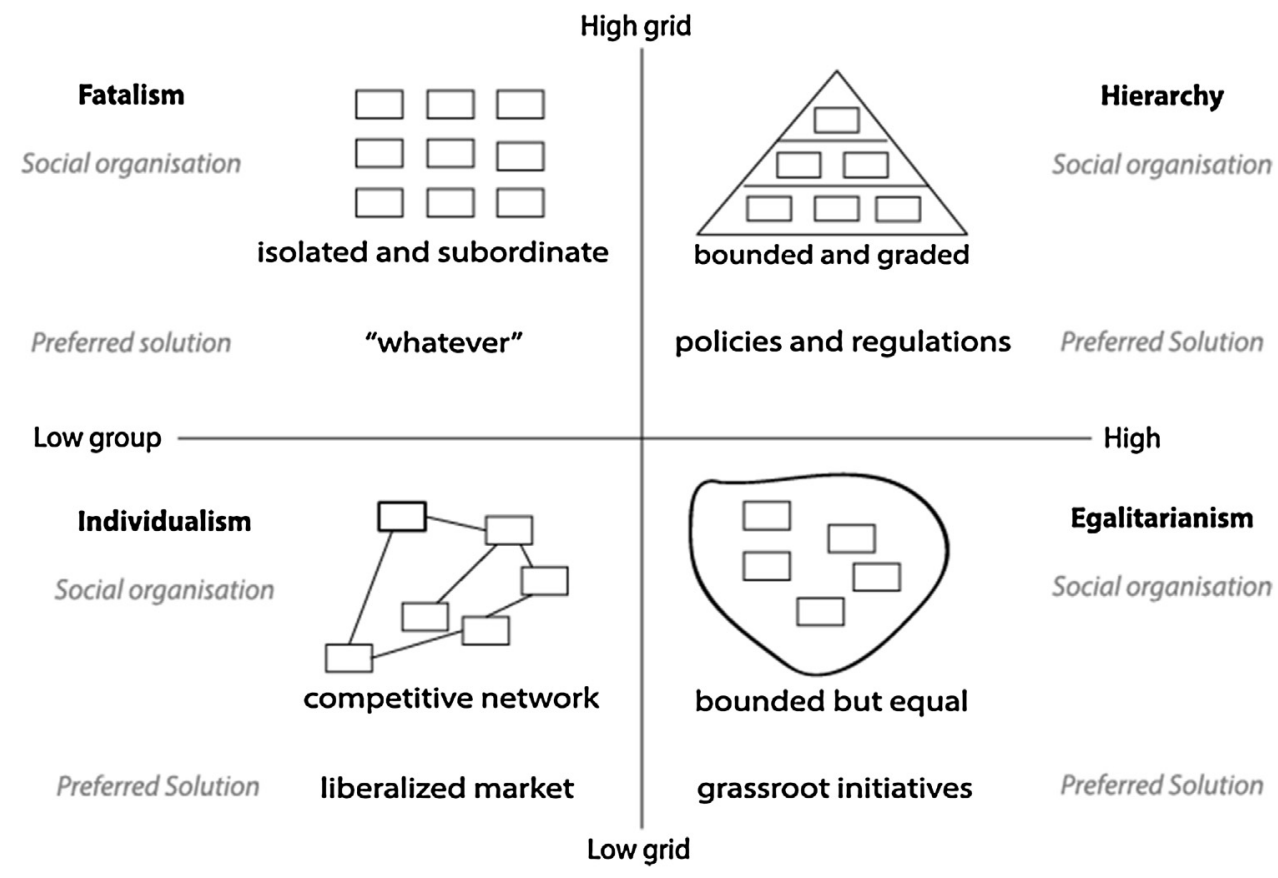

Fig. 1. The rationalities of cultural theory. Adapted from Ref. [53].

Table 1

Summary of the storyline elements.

\begin{tabular}{ll}
\hline & What it means \\
\hline The heroes & The actors solving the problem \\
The problem & The problem to be solved \\
The villain & The ones who caused the problem \\
The solution & How to solve the problem \\
The benefits & The good things that come when the \\
& end-state aim has been achieved \\
The transition & The actions and policies necessary to \\
& implement the solution \\
The barriers & The unexpected complicating twist
\end{tabular}

problem to be solved and the villain who is perceived to have caused the problem; as well as the moral - the solution and its benefits of the storyline, including the barriers in the way of achieving the desired end-state aim (see Table 1).

\section{Results}

\subsection{The organisation Desertec Foundation}

The root of what is today the Desertec Foundation was the Trans-Mediterranean Renewable Energy Cooperation(TREC), much centred around the German physicist Gerhard Knies, with the Club of Rome as the main backing organisation [18]. The Desertec/TREC vision was translated into the Desertec concept (Med-CSP and Trans-CSP studies), foreseeing point-to-point imports of controllable concentrated solar power (CSP) via highly efficient high-voltage direct-current (HVDC) lines from MENA to Europe, by a team of researchers at the German Aerospace Centre (DLR) $[23,63]$ (see Section 4.2 .3 for details on why CSP is controllable). The Desertec Foundation - founded in 2009 - "is committed to the worldwide implementation of the DESERTEC concept: a solution in the fight for a sustainable global energy policy and thus also for security, peace and social stability" [64]. The foundation capital was donated by a number of individuals, of which many are still active in the Foundation, and the Club of Rome; the funding comes from donations from private persons, industry and other foundations [65].

The Dii (formerly the Desertec Industrial Initiative) was founded in 2009 by the Munich Re insurance company, and consisted of 11 large, mainly German companies and the Desertec Foundation [66]. It immediately received broad support for the idea, including from the German federal government [67]. Whereas Dii was founded to push the Desertec concept, the industrial consortium quickly deviated from the "original concept", for which the controllability of CSP and point-to-point HVDC lines are key, and instead searched for cost-optimal renewable electricity expansion paths with large imports of wind and PV power to Europe from MENA via a vast interconnected HVAC grid [68]. The split between the two Desertec organisations became evident when the Desertec Foundation left the Dii consortium in 2013, taking the Desertec brand name with it, because of irresolvable conflicts regarding "strategies, obligations and [...] the managerial style of Dii's top management" [69], triggered by the Dii CEO's interview statements that solar power imports to Europe are unfeasible [70]. Today, Dii still exists but is hardly present in the public debate.

The work and ideas of TREC/Desertec Foundation were influential in the creation of the Mediterranean Solar Plan (MSP), foreseeing the construction of $20 \mathrm{GW}$ renewable power in the southern/eastern Mediterranean basin, under the umbrella of the Union for the Mediterranean in 2008; the Desertec Foundation/TREC is widely seen as "the father of the Solar Plan" [66,71-73]. Desertec is present in the European Commission's long-term decarbonisation strategy, which seeks ways to "harness the solar energy potential of the Sahara" and to develop "pan-European electricity highways" to integrate remote renewables [1].

\subsection{The Desertec storyline}

\subsubsection{The heroes}

In the Desertec storyline, the central protagonists are national and European policy-makers. These must introduce an "adequate policy and economic framework" to enable the construction of CSP stations in MENA and large-scale imports of controllable solar 
power to Europe, for example in an EU-MENA electricity treaty or by including imported CSP in national support schemes [19,23,74]. Other key actors in the Desertec storyline are scientists and energy experts, especially the team at DLR that developed the "original concept" of controllable CSP imports through point-to-point HVDC lines to Europe $[19,24,68,75]$. As long as the transition is secure and rapidly brings humanity under the carrying capacity, it is not important who builds and operates the new electricity system [18]. However, an expansion carried out only by citizens and small-scale investors "cannot attain the sustainable supply required to meet the energy needs of fast-growing cities": to gain sufficient speed "large corporations can play a useful role" [24]. A centralised system structure with large generators and transmission lines is beneficial, because "the power production costs of energy providers are significantly lower than that of private production" [24].

\subsubsection{The problem and the villain}

At the beginning of the Desertec storyline stands mankind as the villain, and an intertwined complex of a growing world population and its dependence on finite resources, in particular water, fossil and nuclear fuels. The resulting violation of the Earth's carrying capacity is a threat to prosperity and, ultimately, to the survival of mankind. The strain on the water resources is already now hindering the economic and social development of poor countries, especially those with deserts, and this problem will increase with climate change, reinforcing the already grave and immoral inequalities between North and South. This "incompatibility between world population and earth's carrying capacity will lead to major disasters", or even the "collapse of civilization", unless we develop and implement a plan to solve the problem ([76], also Refs. $[19,63,77])$.

All continents have sufficient resources for complete power system decarbonisation with the only non-finite energy resource available-renewables. In Europe, however, the feasible renewable potential is near the current electricity demand, so that Europe may encounter resource constraints in the future. Even more importantly, " $60 \%$ of this potential comes from [... f fluctuating resources that can provide electricity, but almost no firm power capacity on demand" [23]. Solving this fluctuation problem domestically within Europe would require storage and other expensive technical solutions, thus causing a cost problem which could make the transition to renewables infeasible [78].

\subsubsection{The solution and the benefits}

The Desertec concept is a plan for mankind to live within the limits of the Earth's carrying capacity as quickly as possible without threatening energy security. To achieve this, "there is no alternative to a rapid expansion of renewable energies, including electricity imports from deserts"v [79]. The Desertec concept combines the greatest assets of MENA - deserts - and Europe - technology - in order to "combat climate change, ensure a reliable energy supply and promote security and development by generating sustainable power from the sites where renewable sources of energy are most abundant" [80].

The Desertec concept foresees large-scale expansion of domestic renewables and the import of controllable CSP electricity from the Sahara and Arab deserts to Europe. The main benefit of CSP over other renewables such as photovoltaic or wind power is that it can be equipped with heat storages and draw on these to generate power when there is no sun, so that CSP is not fluctuating but can be regulated to fit demand. Therefore, CSP adds a controllable renewable electricity source, something that Europe sorely needs to balance its domestic, fluctuating generation [24]. Desertec is a vision that "simultaneously tackles efficiently all the global challenges [and] offers new options for prosperity and development" [19], so that "clean power from deserts is not the only available source of clean energy, but it is practically the only one which is available without source limitations and simultaneously at economically viable conditions" [76].

Desertec thus provides the answer to the resource, cost and variability problems accompanying all other European renewables solutions. It solves the resource problem, as "within $6 \mathrm{~h}$ deserts receive more energy from the sun than mankind consumes within a year" [19]. Building CSP stations on $0.3 \%$ of the world's deserts - land that is practically empty - would suffice to produce the current world electricity demand. As $90 \%$ of the world population live within $3000 \mathrm{~km}$ from a desert and can be efficiently supplied with desert power via HVDC, Desertec is a blueprint for sustainable, secure and cost-efficient electricity not only for Europe and MENA, but for the whole world [19].

The cost of renewables depends largely on the resource quality, and hence a low-cost renewable future requires generation only "in regions of best performance and abundance, distributed all over Europe and MENA" [23]. Because of the better solar resource, Desertec argues, it is cheaper to build a CSP plant in Morocco and transport the electricity to Spain via HVDC than to build the plant directly in Spain [74].

There are four main benefits for MENA. First, Desertec will make cheap renewable electricity capacities available for the growing MENA economies. The core principle of Desertec is to first ensure that the MENA electricity demand is satisfied and then to export to Europe. This will also reduce the need for energy subsidies, which are today a serious drain on many MENA state budgets $[18,63]$. Second, the exporting state can use the CSP export revenues to finance infrastructure, education, to expand domestic electricity generation or import food to overcome its water crisis $[23,75]$ Third, expanding solar power in the desert will attract investment and create qualified jobs in the MENA region. This will ensure that the wealth generated by the exports reaches the people, and not only the elites, and help to build an educated middle class. These points together ensure that Desertec will "create jobs and economic wealth and hence constitute prosperity" in MENA [24,75]. This will make Desertec attractive to the exporters, but also to Europe: as it leads to "the creation of education and employment opportunities as well as better general living conditions, Desertec is an ideal antiterror program" [24]. Fourth, the "huge solar energy potentials of MENA can easily produce the energy necessary to avoid the threatening freshwater deficit" [81]: the waste heat from the CSP stations can be used for large-scale seawater desalination.

In this sense, Desertec can be "the starting point for EUMENA as a region of cooperation, peace and prosperity, much as the coal and steel community was the origin of a cooperating, peaceful and prosperous Europe" [18]. When implemented, Desertec will lead to "prosperity for all peoples involved" [82].

\subsubsection{The transition and the barriers}

The technologies needed - CSP and HVDC - are available today and "have been in use for decades" [75]. The transition from coal and nuclear power to an inter-continental renewable power system is therefore only a political problem: "all that is needed now is the political will and the right framework of incentives" [75]. If the political will is present, "it would be possible to achieve a worldwide realisation of the Desertec concept in less than 30 years" [19], by launching "an Apollo-like 'EUMENA-Desertec' program” [77]. Initial state-support, like "feed-in tariffs and investment guarantees are needed to get things moving" [75], but "no long-term subsidies like for fossil or nuclear energies" [63] as renewables experience strong learning effects and are already cheaper than conventional power, if conventional generators paid their external costs. This initial support, summing up to 10 billion $€$ for all European coun- 
tries together, should therefore "be considered a public investment rather than a subsidy" ([23], also Ref. [18]).

\subsection{The organisation Eurosolar}

Eurosolar - the European Association for Renewable Energy was founded in 1988 on initiative of the German politician Hermann Scheer. It is a European organisation, but the German section, which is by far the largest, is dominant. The Eurosolar vision is based on ideas expressed in Scheer's writings, which remain influential also after his death in 2010. Eurosolar is committed to "completely replacing nuclear and fossil energy with renewables [which is] the central precondition for the preservation of nature and a sustainable economic strategy"vi [83]. Its roots lie in the anti-nuclear power movement of the 1970s and 1980s, and Eurosolar ideas draw strongly on the subsidiary principles expressed in Agenda21 [22,84-87]. Eurosolar is a not-for-profit organisation funded mainly by membership fees and revenues from events and publications; by far most members are individuals and a small share are juridical persons [17].

The political impact of Eurosolar can be seen in particular in the German feed-in law, drafted and propagated by, among others, Scheer $[4,88]$. Especially the early versions of the law holds most parts of the Eurosolar storyline and justify the law by local value and job creation, introducing the aim of the law as one to not only increase the share of renewables but to ensure "that especially decentralised smaller installations become the pillar of the future energy supply"vii [89] (see Section 4.4.4). Further, Eurosolar was highly influential in the creation of the International Renewable Energy Agency (IRENA), which became operational in 2010 $[90,91]$; because of his instrumental role, Scheer is acknowledged as "the father of IRENA" [92].

\subsection{The Eurosolar storyline}

\subsubsection{The heroes}

Following the Agenda21 maxim "think globally, act locally", the central protagonists in the Eurosolar story are citizens - either as individuals or partners in an energy cooperative - municipalities and public utilities [85]. Citizens are key the actors, both pushing for change locally and implementing the transition themselves $[22,85,93]$. Municipalities are key enablers, both by appointing priority areas for renewables in the zoning policy, thus enabling citizens to build renewable generators, and by expanding generation and consumption of renewables themselves (or through a municipal utility) [87,94]. It is equally important that the energy majors - the "structural enemies"viii of renewables - are not part of the renewable energy future, as they have caused the very problem Eurosolar seeks to solve and have much to gain from stopping the transition [22].

\subsubsection{The problem and the villain}

At the heart of the Eurosolar storyline is the villain: the fossilnuclear complex - the traditional major energy companies and its cronies in policy - and the centralised electricity system it has created. The fossil-nuclear complex has created four interrelated crises threatening society and the people in it: dependence on ever-scarcer fossil energy resources and the concentration of remaining resources in unstable regions; dependence on increasingly costly and peace-threatening energy imports; "unsolved and unsolvable"ix nuclear risks; and climate change and environmental degradation ([22], also Refs. [84,94-96]). Continuing within the centralised energy paradigm threatens to "plunge civilization into an all-enveloping crisis [...] trigger misery and migration for hundreds of millions of people [while] conflicts, including resource wars, over access to the last energy resources loom"x [22]; on the horizon are the "return to barter trade [...] mass unemployment, state bankruptcies [...] and ultimately famine"xi [96]. Hence, replacing the fossil-nuclear energy system - "the largest economic and social problem of the 21st century"xii [97] - with a decentralised, fully renewable one is imperative.

However, as the survival of the fossil-nuclear complex is threatened, it will try to stop the transition to renewables "before the benefits become visible to all and renewables become unstoppable"xiii [98]. As the fossil-nuclear complex is "the largest and politically most influential sector in the world economy [it is] naïve to think that this is frictionless and possible to realise in consensus with the incumbents of traditional energy supply"xiv [84]. Defeating the fossil-nuclear complex is thus the key task of the energy transition: decentralisation is a precondition for decarbonisation.

\subsubsection{The solution and the benefits}

The solution to these problems is energy autonomy, which means not only local or regional energy autarky, but "self-determined energy-free and independent of external pressures, coercion and interventions" $\mathrm{xv}$ [84]. The future energy supply must be "efficient, decentralised and regenerative"xvi [94], and "self-sufficiency in energy, through renewable energy systems, is the only acceptable perspective for the future"xvii [62].

Importantly, energy autonomy is not only about technological change, but about a change in actors: it is necessary that "not only the relationship between renewable and fossil-nuclear electricity changes, but also the structure of energy producers"xviii [99]. Reducing the discussion to one about power mixes and costs is a "systemic misunderstanding", originating in the "market autism"xix of the current energy system and policy-thinking [22].

The potential for renewables in Germany, Europe and the world are sufficient for $100 \%$ renewable energy [84]. Indeed, for supplying all of Germany's electricity needs with PV and onshore wind power, "only $2-3 \%$ of the country need to be made available"xx [97]; "no less than half of the problem"xxi would be solved by replacing all red roof tiles with the blue glow of solar panels [84]. Contrary to what the fossil-nuclear complex makes people believe, decentral renewables are not expensive but rather "the solution to the cost problem"xxii [97]: "the primary energy is free and available in the long run" and the costs for renewable generators are decreasing rapidly, so that renewables are cheaper than "conventional energies with their increasing fuel costs"xxiii [22], especially if external costs are accounted for.

The fluctuations of wind and solar power, which critics erroneously believe will stop the transition soon, can be handled locally or regionally with decentral storages and by combining fluctuating and dispatchable renewable generators into virtual renewable power plants. For this, however, the current energy paradigm must be overcome and the power system operations adapted to the technical features of renewables, instead of renewables being adapted to the needs of fossil-nuclear power [22,97].

The short distance from generation to consumption is "the systemic advantage of renewable energies"xxiv [84,100], avoiding "the complex technical, organisational, administrative and political, all the way to military, expenses needed for the long way from extraction to end-use of nuclear and fossil energies"xxv [84,101]. Furthermore, and unlike the fossil-nuclear energy system, the local value and job creation is substantive: 380,000 persons worked in the German renewable energy business in 2012 [85,94,97]. A locally autarkic renewable energy supply, finally, eliminates the need for costly and risky energy imports, which improves energy security and the trade balance; in 2012, "the trade balance deficit of the EU27 states was about 100 billion $€$, and the import bills for fossil fuels were over 400 billion $€$ "xxvi [96]. Europe does not need 
Table 2

Summary of the Desertec and Eurosolar storylines.

\begin{tabular}{|c|c|c|}
\hline & Desertec & Eurosolar \\
\hline The heroes & $\begin{array}{l}\text { - Experts (engineers, scientists) } \\
\text { - Energy companies } \\
\text { - National, European policy }\end{array}$ & $\begin{array}{l}\text { - Citizens/citizen initiatives } \\
\text { - Municipal utilities } \\
\text { - Municipalities / regional policy }\end{array}$ \\
\hline The villain & - Mankind & - The fossil-nuclear complex \\
\hline The problem & $\begin{array}{l}\text { - Mankind's hunger for resources violate the Earth's carrying } \\
\text { capacity } \\
\text { - Renewables in Europe are fluctuating; domestic grid integration } \\
\text { measures are expensive }\end{array}$ & $\begin{array}{l}\text { - Increasing fossil fuel costs } \\
\text { - Fossil fuels running out, dependence increasingly risky and } \\
\text { peace-threatening } \\
\text { - Climate change and environmental degradation } \\
\text { - Nuclear risks }\end{array}$ \\
\hline The solution & $\begin{array}{l}\text { Desertec concept: } \\
\text { - Masterplan for renewables, including solar power imports from } \\
\text { deserts to Europe, to achieve sustainability quickly while } \\
\text { maintaining energy security }\end{array}$ & $\begin{array}{l}\text { Energy autonomy: } \\
\text { - Rapid decentralisation of electricity system with renewables } \\
\text { - Local autonomous initiatives, individual citizens/groups, } \\
\text { municipal utilities expand renewables }\end{array}$ \\
\hline The benefits & $\begin{array}{l}\text { - Abundant sustainable electricity } \\
\text { - Low-cost secure electricity } \\
\text { - Europe-MENA integration } \\
\text { - Improved socio-economic development in MENA }\end{array}$ & $\begin{array}{l}\text { - Democratisation of energy } \\
\text { - Independence } \\
\text { - Abundant, cheap, environmentally friendly electricity }\end{array}$ \\
\hline The transition & $\begin{array}{l}\text { - Starts as soon as there is political will } \\
\text { - Initial subsidies and policies for imported renewable electricity }\end{array}$ & $\begin{array}{l}\text { - Is already happening } \\
\text { - Grass root initiatives supported by feed-in tariffs }\end{array}$ \\
\hline The barriers & - Lack of political will & - Resistance and power of fossil-nuclear complex \\
\hline
\end{tabular}

"more oil sheikhs in the desert, but value creation, taxes and jobs at home"xxvii [21,22].

\subsubsection{The transition and the barriers}

The transition to a sustainable energy future can only emerge from autonomous renewables initiatives in municipalities and societies: it cannot be managed top-down, although policy must support with an appropriate framework. After all, "a technological revolution does not happen through technology itself, but through the people who seize the new opportunities"xxviii [22].

Such a framework already exists in Germany: the Renewable Energies Act (EEG-Erneuerbare-Energien-Gesetz), which is "the most successful concept for the implementation of the energy transition in the world“xxix ([97], also [21,22,86,100]). This law regulates the priority feed-in for renewables and determines a guaranteed price at different levels for different renewable technologies. The EEG seeks to leverage investments from multiple actors, to support local value creation and a new national renewables industry, and make renewables - especially decentralised renewables - the carrying pillar of the future electricity system (see Section 4.3) [89,102,103]. It has enabled hundreds of citizens' initiatives and thousands of single citizens to build renewable power stations, decentrally and without policy or industry telling them what to do: $30 \%$ of German electricity is already renewable. More than half of this is owned by citizens/initiatives and farmers, whereas the major energy companies own only 6.5\% [85]. Especially the modular structure of decentralised renewables is an accelerating factor, as it allows a multitude of actors - from single citizens to municipal utilities - to pursue their own transition [22,85,104]. Hence, the decentralised energy transition is more than a vision: it is already happening.

Although several villages and municipalities have achieved $100 \%$ renewable energy or electricity supply [99,105], Germany as a country has not, and neither has the EU. For the continuation of the energy transition, re-nationalisation or municipalisation of electricity grids is important, to allow "democratic control" $\mathrm{xx}$ of the physical marketplace for electricity and to stop the energy majors from continuously abusing of their power over the electric- ity grid [22]. Further, politicians must continue the successful path of the EEG without listening to the fear mongering of the fossilnuclear lobby. In the end, public costs arising from the EEG and the continued expansion of decentralised renewables "would not be a subsidy, but rather a premium for avoiding societal harm"xxxi [22].

\subsection{Storyline comparison}

At first sight the two storylines have much in common, such as the view of renewables as the only solution to dwindling fossil energy resources, their rejection of nuclear power, the urge to combat climate change, and the recognition that the sun shines for free. The perceptions of the consequences of failing to transform the electricity system - social, political and economic turmoil - are similarly dramatic. In both storylines, renewables would be competitive already today if nuclear and fossil power would pay for their external costs.

Yet, although the addressed environmental problems are similar, the heroes, villains, and the problems to solve are different, leading to fundamentally diverging transition strategies and endstate aims (see Table 2).

The heroes of Desertec are energy experts, energy companies and national or European policy-makers. These actors are at the top of the hierarchical system and Desertec looks to them to guide Europe (and eventually mankind) to sustainability through active policy and regulation based on scientific facts. To Desertec, this is necessary, as mankind is not capable of saving itself. Eurosolar, in contrast, sees most Desertec heroes as villains (see below) and instead views citizens, grass-root initiatives, local policy-makers and utilities as its heroes. These actors will bring about the needed transition through a multitude of local initiatives. To Eurosolar, this is necessary, as we can achieve the transition and reach energy autonomy only through decentralisation and democratisation everybody must be accountable and a part of the change.

To Desertec, the villain is mankind and the problem is its hunger for resources and the resulting violation of the Earth's carrying capacity. For Eurosolar, the villain is the fossil-nuclear complex, whose centralised energy system has built us into a risky depen- 
dence on finite and environmentally harmful energy resources that threatens peace and prosperity. Hence, to Desertec the solution lies in guiding mankind in a more secure direction, namely increased reliance on controllable renewables, generated at home and in the desert. Eurosolar, in contrast, sees that we - the citizens, including our direct municipal representatives - must rid society of the fossilnuclear complex, as its powerful actors would otherwise sabotage the already ongoing transition to a sustainable future. Renewables are highly suited for this, as they are both decentralised and environmentally friendly.

Desertec sees itself as blocked by a lack of political will to implement the Desertec concept: it could be done today, if only politicians understood the need and the benefits and adjusted the policy framework to accommodate controllable CSP imports via point-to-point HVDC lines. Eurosolar instead sees the resistance of the powerful fossil-nuclear complex as the main barrier, as its very existence is threatened by decentralisation. A striking difference is that the Desertec transition is something that should happen in the future (and likely will happen, once politicians understand), whereas the Eurosolar decentralised energy transition is already happening and simply needs to be continued and accelerated (and grass-root movements will continue to carry out the transition, unless politicians listen to the fossil-nuclear lobby).

\section{Discussion}

\subsection{What is the disagreement between Eurosolar and Desertec about?}

The comparison of the two organisations' storylines show that they, behind the headline rhetoric of $100 \%$ renewables, strive to achieve very different renewable electricity futures in very different ways. Eurosolar emphasises democratisation and autonomy through decentralisation as the prime aim, and renewables - being of a small-scale and modular nature - are excellently suited for this. Furthermore, Eurosolar views decentralisation as a necessary precondition for decarbonisation: climate-friendliness cannot be achieved if the fossil-nuclear complex, which caused the problem in the first place, is still powerful. To Eurosolar, the economic attractiveness originates in local value creation and the removal of greedy energy majors. Desertec, in contrast, sees secure decarbonisation as the main goal and concerted policy action and large-scale investment as the means to achieve it. Imports of controllable CSP through long HVDC power lines are the key to balancing the domestic European wind and solar PV generation. This trade also leads to economic, political and security benefits of integrating Europe and the Arab world. To Desertec, economic attractiveness comes from superior solar resources in the desert and the cheap system balancing with controllable imported solar power. The two organisations' visions are thus only superficially similar given their concern for $100 \%$ renewables: their envisioned end-state aims and governance choices, including the actors to carry out the change, are in fact fundamentally different.

\subsection{Is a compromise possible or are the two visions mutually exclusive?}

Comparing these findings to the theoretical vision classifications in literature (Section 2), it becomes clear that we have empirically observed two visions following different normative aims and governance pathways, coherent with the theoretical literature. Although the theoretical concepts are different, they explain the same vision divide, for largely the same reasons. In Cultural Theory terms, Desertec follows a Hierarchical rationality, relying on topdown policy and controllable large-scale solutions with security of the decarbonisation as a key constraint. Eurosolar, in contrast, is Egalitarian, relying on bottom-up initiatives and small-scale investment with equity as the key constraint. Viewing it through Foxon's Logics, Desertec follows a Government Logic whereas Eurosolar follows a Civil Society Logic, for largely the same reasons as in the CT classification; in Lovins' terms, Desertec is a Hard energy path, although it is based on renewables, whereas Eurosolar is Soft.

Both coalitions seek a completely renewable electricity system, but in very different ways, for diverging reasons and with conflicting governance paths. Desertec can, and claims to do, accept the inclusion of decentralised renewables as a part of the future electricity system, as long as controllable solar power imports are the securing pillar of supply. Expanding renewables in the Desertec way, including large solar power stations and large and long power lines, however violates the core aim of Eurosolar, which precludes precisely such large assets and the companies owning them. As it is hardly possible to import CSP from deserts to Europe in a decentralised way, it is difficult to imagine a compromise that includes controllable CSP imports and is still acceptable to Eurosolar. To Eurosolar, the suggested consensus between Desertec's and Eurosolar's $100 \%$ renewables aim is an illusion that is "perfectly designed to maintain the old energy world order, albeit it with renewables"xxxii [106]. This is consistent with Lovins' statement that "it is important to recognize that the two paths [Hard and Soft] are mutually exclusive" [45].

This indicates that the idea of Battaglini et al. [40] to solve the centralised-decentralised controvery by merging them into a SuperSmart Grid vision is impractical: from a technical perspective, the two visions can co-exist, but politically the two visions are irreconcilable as their end-state aims and desired actor and governance structures clash. This is especially clear when comparing the core aims: Eurosolar's core aim of decentralisation precludes the incorporation of centralised aspects, but such assets are the core of Desertec. Hence, a compromise would require one vision to abstain from its core aim. Such a solution, however, is hardly a true compromise - or a clumsy solution [59] - but rather one vision becoming dominant and forcing the other to give up its key identity: Desertec without CSP imports would not "be Desertec", and Eurosolar's vision would be nothing if the decentralisation aim is removed. Hence, and regardless of whether their secondary aims are compatible or not, a real compromise will be difficult, or impossible, as the core aims of the two visions are irreconcilable.

\subsection{Outlook}

Our study shows that the roots of the investigated controversy are differences in normative end-state aims and governance solutions for achieving these aims, and not primarily in technology, power mix pie-charts or costs. We have thus empirically shown that energy vision divides such as those theoretically derived in the literature indeed exist, and that actors use such different visions, suggesting that differences in aims and governance pathways are key drivers of the general energy policy debate. We have shown that controversies similar to that between renewables and nuclear power - controversies that can hardly be solved with more optimisation modelling, pie-charts and cost estimates - also exist, in at least one case, between proponents of a fully renewable future, because there are fundamentally different and mutually exclusive visions for how a future renewable power system should look and be governed.

The core of the Desertec-Eurosolar controversy is about centralisation or decentralisation, about governance and ownership, and yet such issues are rarely explicated in energy policy debates. Explicitly acknowledging differences in normative objectives between different renewables pathways and seeking compromises concerning soft issues beyond hard facts such as technology, costs 
or the "necessity" for more transmission, could thus reduce conflict about the energy transition.

Similarly, scientific electricity system models miss, or ignore, issues beyond the techno-economic realm. Yet, normative issues about which energy future we want are key drivers for support or opposition to policies and projects-and hence greatly important for costs and a scenario's chances of realisation (see Ref. [107]). We thus call for future researchers, in particular electricity system modellers, to assess more than one type of system (e.g. including decentralised scenarios) and to make their underlying vision transparent: explicitly including the normative frames that guide the researchers' search for a better future, including how the system is governed, could make the modelling effort more rigorous and policy-relevant.

\section{Acknowledgements}

Funding for this work came from a European Research Council consolidator grant, contract number 313533.

\section{Appendix A. Supplementary data}

Supplementary data associated with this article can be found, in the online version, at http://dx.doi.org/10.1016/j.erss.2016.03.011.

\section{References}

[1] EC, Energy roadmap 2050, $\operatorname{COM(2011)~885,~European~Commission~(EC),~}$ Brussels, 2011.

[2] GEA, Global Energy Assessment, Cambridge University Press, Cambridge, 2012.

[3] ECF, Roadmap 2050, European Climate Foundation, Den Haag, 2010.

[4] A. Patt, Transforming Energy: Solving Climate Change with Technology Policy, Cambridge University Press, Cambridge, 2015.

[5] IPCC, Climate Change 2007. The Physical Science Basis, Intergovernmental Panel on Climate Change (IPCC), Geneva, 2007

[6] J. Roose, Der endlose streit um die atomenergie, in: P. Feindt, T. Saretzki (Eds.), Umwelt-und Technikkonflikte, VS Verlag, Wiesbaden, 2010.

[7] F. Berkhout, Normative expectations in systems innovation, Technol. Anal. Strateg. Manage. 18 (2006) 299-311, http://dx.doi.org/10.1080/ 09537320600777010.

[8] S. Jasanoff, S.-H. Kim, Sociotechnical imaginaries and national energy policies, Sci. Cult. 22 (2013) 189-196, http://dx.doi.org/10.1080/09505431. 2013.786990

[9] E. Trutnevyte, The allure of energy visions: are some visions better than others? Energy Strateg. Rev. 2 (2014) 211-219, http://dx.doi.org/10.1016/j. esr.2013.10.001.

[10] W. Haefele, et al., Energy in a Finite World, Ballinger Publishing Company, Cambridge, 1981

[11] E. Schmid, B. Knopf, A. Pechan, Putting an energy system transformation into practice: the case of the German Energiewende, Energy Res. Soc. Sci. 11 (2015) 263-275, http://dx.doi.org/10.1016/j.erss.2015.11.002.

[12] N. Nakicenovic, et al., IPCC Special Report, Emissions Scenarios, Intergovernmental Panel on Climate Change (IPCC), Geneva, 2000.

[13] E. Trutnevyte, et al., Linking a storyline with multiple models: a cross-scale study of the UK power system transition, Technol. Forecast. Soc. Change 89 (2014) 26-42.

[14] A. Correljé, C. van der Linde, Energy supply security and geopolitics: a European perspective, Energy Policy 34 (2006) 532-543, http://dx.doi.org/ 10.1016/j.enpol.2005.11.008.

[15] A. Stirling, Transforming power: social science and the politics of energy choices, Energy Res. Soc. Sci. 1 (2014) 83-95, http://dx.doi.org/10.1016/j. erss.2014.02.001.

[16] H. Degenhart, et al., Definition und Marktanalyse von Bürgerenergie in Deutschland, trend:research, Bremen (2013).

[17] Eurosolar, Who We Are, Eurosolar. http://www.eurosolar.de/en/index.php/ about-us-mainmenu-52 (23.11.15).

[18] G. Knies, U. Möller, M. Straub (Eds.), Clean Power from Deserts, Club of Rome, Hamburg, 2008.

[19] Desertec, Red Paper, Desertec Foundation, Hamburg, 2009.

[20] H. Scheer, Wüstenstrom für Europa ist eine Fata Morgana, Eurosolar. http:// www.hermannscheer.de/de/index.php?option=com content\&task=view\&id=662\&Itemid=173 (07.03.13).

[21] Eurosolar, Die Energiewende findet dezentral statt!, Eurosolar. http://www. eurosolar.de/de/index.php/aktuell-mainmenu-254/1696-dieenergiewende-findet-dezentral-statt (07.03.13).

[22] H. Scheer, Der Energethische Imperativ, Kunstmann, München, 2010.
[23] DLR, Trans-Mediterranean Interconnection for Concentrating Solar Power, German Aerospace Centre (DLR), Stuttgart, 2006.

[24] Desertec, Questions and Answers, Desertec Foundation. http://www. desertec.org/en/concept/questions-answers/, (11.03.13).

[25] IPCC, Special Report on Renewable Energy Sources and Climate Change Mitigation, Cambridge University Press, Cambridge, 2011.

[26] B. Sovacool, What are we doing here? Analyzing fifteen years of energy scholarship and proposing a social science research agenda, Energy Res. Soc. Sci. 1 (2014) 1-29, http://dx.doi.org/10.1016/j.erss.2014.02.003.

[27] P. Capros, et al., European decarbonisation pathways under alternative technological and policy choices: a multi-model analysis, Energy Strateg. Rev. 2 (2014) 231-245, http://dx.doi.org/10.1016/j.esr.2013.12.007.

[28] J. Lilliestam, et al., More than costs: on the fit between solar and renewable electricity policy motivations and energy system models, in: S. Bailey (Ed.), Solar power: Technologies, Environmental Impacts and Future Prospects, Nova, Hauppage, 2014, pp. 23-56.

[29] S. Pfenninger, A. Hawkes, J. Keirstead, Energy systems modeling for twenty-first century energy challenges, Renew. Sustain. Energy Rev. 33 (2014) 74-86, http://dx.doi.org/10.1016/j.rser.2014.02.003.

[30] B. Elliston, I. MacGill, M. Diesendorf, Least cost $100 \%$ renewable electricity scenarios in the australian national electricity market, Energy Policy 59 (2013) 270-282, http://dx.doi.org/10.1016/j.enpol.2013.03.038.

[31] H. Lund, B. Mathiesen, Energy system analysis of $100 \%$ renewable energy systems-the case of Denmark in years 2030 and 2050, Energy 34 (2009) 524-531, http://dx.doi.org/10.1016/j.energy.2008.04.003.

[32] SRU, Pathways Towards a 100\% Renewable Electricity System, German Advisory Council on the Environment (SRU), Berlin, 2011.

[33] M. Jacobson, et al., Low-cost solution to the grid reliability problem with $100 \%$ penetration of intermittent wind, water, and solar for all purposes, PNAS 112 (2015) 15060-15065, http://dx.doi.org/10.1073/pnas. 1510028112 .

[34] R. Rodríguez, et al., Transmission needs across a fully renewable European power system, Renew. Energy 63 (2014) 467-476, http://dx.doi.org/10. 1016/j.renene.2013.10.005.

[35] G. Czisch, Szenarien zur zukünftigen Stromversorgung, Doctoral Dissertation, Universität Kassel, Kassel, 2005.

[36] G. Plessmann, et al., Global energy storage demand for a $100 \%$ renewable electricity supply, Energy Procedia 46 (2014) 22-31, http://dx.doi.org/10. 1016/j.egypro.2014.01.154.

[37] J. Byrne, N. Toly, Energy as a social project: recovering a discourse, in: J. Byrne, N. Toly, L. Glover (Eds.), Transforming Power: Energy, Environment, and Society in Conflict, Transaction Publishers, New Brunswick, 2006, pp. $1-32$.

[38] B. Sovacool, M. Brown, Deconstructing facts and frames in energy research: maxims for evaluating contentious problems, Energy Policy 86 (2015) 36-42, http://dx.doi.org/10.1016/j.enpol.2015.06.020.

[39] M. Thompson, S. Rayner, S. Ney, Risk and governance, part II: policy in a complex and plurally perceived world, Gov. Oppos. 33 (1998) 330-354.

[40] A. Battaglini, et al., Development of SuperSmart Grids for a more efficient utilisation of electricity from renewable sources, J. Clean. Prod. 17 (2009) 911-918, http://dx.doi.org/10.1016/j.jclepro.2009.02.006.

[41] I. Illich, Energy and Equity, Calder and Boyars, London, 1973.

[42] L. Glover, From love-ins to logos: charting the demise of renewable energy as a social movement, in: J. Byrne, N. Toly, L. Glover (Eds.), Transforming Power, Transaction Publishers, London, 2006, pp. 249-270.

[43] C. Mitcham, J. Smith Rolston, Energy constraints, Sci. Eng. Ethics 19 (2013) 313-319, http://dx.doi.org/10.1007/s11948-013-9446-3.

[44] A. Lovins, Soft energy technologies, Annu. Rev. Energy 3 (1978) 477-517.

[45] A. Lovins, Energy strategy: the road not taken? Foreign Aff. 55 (1976) 65-96.

[46] T. Foxon, et al., Branching points for transition pathways: assessing responses of actors to challenges on pathways to a low carbon future, Energy Policy 52 (2013), http://dx.doi.org/10.1016/j.enpol.2012.04.030.

[47] T. Foxon, Transition pathways for a UK low carbon electricity future, Energy Policy 52 (2013) 10-24, http://dx.doi.org/10.1016/j.enpol.2012.04.001.

[48] F. Geels, J. Schot, Typology of sociotechnical transition pathways, Res. Policy 36 (2007) 399-417, http://dx.doi.org/10.1016/j.respol.2007.01.003.

[49] G. Verbong, F. Geels, Exploring sustainability transitions in the electricity sector with socio-technical pathways, Technol. Forecast. Soc. Change 77 (2010) 1214-1221, http://dx.doi.org/10.1016/j.techfore.2010.04.008.

[50] M. Thompson, Among the energy tribes: a cultural framework for the analysis and design of energy policy, Policy Sci. 17 (1984) 321-339.

[51] I. Scrase, A. Smith, F. Kern, Dynamics and Deliberations: Comparing Heuristics for Low-carbon Innovation Policy, SPRU, University of Sussex, Brighton, 2010.

[52] M. Thompson, R. Ellis, A. Wildavsky, Cultural Theory, Westview Press, Boulder, 1990.

[53] B. Swedlow, Cultural coproduction of four states of knowledge, Sci. Technol. Human Values (37 2011) 151-179, http://dx.doi.org/10.1177/ 0162243911405345.

[54] J. Dryzek, The Politics of the Earth: Environmental Discourses, Oxford University Press, Oxford, 1997

[55] M. Hajer, The Politics of Environmental Discourse: Ecological Modernization and the Policy Process, Clarendon Press, Alderley, 1995.

[56] M. Hajer, W. Versteeg, A decade of discourse analysis of environmental politics: achievements, challenges, perspectives, J. Environ. Policy Plann. 7 (2005) 175-184, http://dx.doi.org/10.1080/15239080500339646. 
[57] V. Lauber, E. Schenner, The struggle over support schemes for renewable electricity in the European Union: a discursive-institutionalist analysis, Environ. Politics 20 (2011) 508-527, http://dx.doi.org/10.1080/09644016. 2011.589578.

[58] M. Hajer, Doing discourse analysis: coalitions, practices, meaning, in: M. van den Brink, T. Metze (Eds.), Words Matter in Policy and Planning, KNAG, Utrecht, 2006, pp. 65-74

[59] M. Verweij, et al., Clumsy solutions for a complex world: the case of climate change, Public Adm. 84 (2006) 817-843.

[60] K. Fløttum, Ø Gjerstad, Arguing for climate policy through the linguistic construction of narratives and voices, Clim. Change 118 (2013) 417-430, http://dx.doi.org/10.1007/s10584-012-0654-7.

[61] I. Scrase, D. Ockwell, The role of discourse and linguistic framing effects in sustaining high carbon energy policy, Energy Policy 38 (2010), http://dx.doi. org/10.1016/j.enpol.2009.12.010.

[62] P. Droege, Ins solare Zeitalter: ein Blick zurück-ein Sprung nach vorn, Solarzeitalter 3 (2013) 4-7.

[63] bDLR, Concentrating Solar Power for the Mediterranean Region, German Aerospace Centre (DLR), Stuttgart, 2005.

[64] Desertec, Desertec Drops Its Own Target? Desertec Foundation. http://www. desertec.org/news/newsletter/130305-04-desertec-drops-its-own-targetsa-comment/ (10.03.13).

[65] Desertec, The Founding Donors, Desertec Foundation. http://www.desertec org/organization/founders-partners/ (23.11.15).

[66] G. Schellekens, et al., Moving Towards 100\% Renewable Electricity in Europe \& North Africa by 2050, PriceWaterhouseCoopers, London, 2011.

[67] BMWi, Rösler and Douiri establish German-Moroccan energy partnership German Ministry for Economic Affairs (BMWi). http://bmwi.de/EN/Press/ press-releases, did=498986.html (01.09.12).

[68] F. Trieb, et al., Rescuing the original concept of solar electricity transfers from North Africa to Europe, DLR. http://www.dlr.de/tt/en/Portaldata/41/ Resources/dokumente/institut/system/publications/BETTER-WP3-ESMReadable-2015-04-21.pdf (07.12.15).

[69] Desertec, Desertec Foundation is leaving the industrial consortium Dii, Desertec Foundation. http://www.desertec.org/press/press-releases/ 130701-desertec-foundation-is-leaving-the-industrial-consortium-dii/ (29.11.15).

[70] EurActiv, Desertec abandons Sahara solar power export dream, EurActiv. http://www.euractiv.com/energy/desertec-abandons-sahara-solar-p-news528151 (23.11.15)

[71] Knies G, Solar Plan (MSP) becomes the flagship project of the Union for the Mediterranean. Press release, Club of Rome. http://www.desertec.org fileadmin/downloads/press/press_release_en_09.pdf (23.11.15).

[72] H.-G. Brauch, et al., Policy responses to climate change in the Mediterranean and MENA region during the Anthropocene, in: J. Scheffran (Ed.), Climate Change, Human Security and Violent Conflict, Springer, Berlin, 2012, pp. 719-794.

[73] UfM, Mediterranean Solar Plan, Union for the Mediterranean (UfM). http:// ufmsecretariat.org/mediterranean-solar-plan-joint-committee-of-nationalexperts-discusses-draft-of-the-master-plan/ (23.11.15).

[74] F. Trieb, H. Müller-Steinhagen, The Desertec concept, in: G. Knies, U. Möller M. Straub (Eds.), Clean Power from Deserts, Club of Rome, Hamburg, 2008, pp. 23-44.

[75] G. Knies, TREC-Clean Power from Deserts, Club of Rome, Hamburg, 2008.

[76] G. Knies, A brief overview on global energy, water and carrying capacity perspectives, in: G. Knies, U. Möller, M. Straub (Eds.), Clean Power from Deserts, Club of Rome, Hamburg, 2008, pp. 16-22.

[77] Prince Hassan, EUMENA-community for a sustainable energy future, in: G. Knies, U. Möller, M. Straub (Eds.), Clean Power from Deserts, Club of Rome, Hamburg, 2008, pp. 5-6.

[78] F. Trieb, T. Fichter, M. Moser, Concentrating solar power in a sustainable future electricity mix, Sustain. Sci. 9 (2014) 47-60, http://dx.doi.org/10. 1007/s11625-013-0229-1.
[79] Greenpeace, FAQ Wüstenstrom, Greenpeace. http://www.greenpeace.de fileadmin/gpd/user_upload/themen/energie/FAQ_Wuestenstrom_01.07.09-f. $\operatorname{pdf}(11.03 .13)$.

[80] Desertec, Our global mission, Desertec Foundation. http://www.desertec. org/global-mission/, (07.03.13).

[81] DLR, Concentrating Power for Seawater Desalinisation, German Aerospace Centre (DLR), Stuttgart, 2007

[82] H. el-Nokraschy, Energy challenges in Egypt, in: G. Knies, U. Möller, M. Straub (Eds.), Clean Power from Deserts, Club of Rome, Hamburg, 2008, pp. 51-52.

[83] Eurosolar, Was is Eurosolar? Eurosolar. http://www.eurosolar.de/de/index. php/er-uns-mainmenu-87 (04.02.14).

[84] H. Scheer, Energieautonomie, Kunstmann, München, 2005.

[85] G. Oelsner, Zivilgesellschaft als motor der energiewende, Solarzeitalter 4 (2012) 100-105.

[86] I. Scheer-Pontenagel, Der Eurosolar-Kampf für das Erneuerbare-Energien-Gesetz (EEG), Solarzeitalter 3 (2013) 1-3.

[87] S. Grüger, F. Longo, Energieautonomie durch landes-und kommunalpolitische Massnahmen, Solarzeitalter 4 (2008) 14-22.

[88] S. Grüger, Ohne EEG keine Energiewende, Solarzeitalter 2 (2015) 17-21.

[89] EEG, Gesetz für den Vorrang Erneuerbarer Energien, Bundesgesetzblatt I 2000, 305, Bonn, 2000.

[90] Lölhoffel H., IRENA ready to start immediately, Eurosolar. http://www. eurosolar.de/en/index.php/irena-mainmenu-103/press-releasesmainmenu-104/354-irena-ready-to-start-immediately (29.11.15)

[91] B. Hirschl, International renewable energy policy-between marginalization and initial approaches, Energy Policy 37 (2009) 4407-4416.

[92] IRENA, Hermann Scheer, father of IRENA, passed away, International Renewable Energy Agency (IRENA). http://www.irena.org/news/ Description.aspx?NType $=$ N\&News_ID $=81 \&$ PriMenuID=16\&Mnu=Pri (23.11.15).

[93] A. Markowsky, Kampf den Pyromanen, Solarzeitalter 4 (2012) 75-78.

[94] K. Berlo, Die Möglichkeiten der Stadtwerke zur Sicherung einer dezentralen Energieversorgung, Solarzeitalter 3 (2008) 72-77.

[95] M. Fischedick, S. Samadi, Die grundsätzliche wirtschaftstheoretische Kritik am EEG greift zu kurz, Solarzeitalter 1 (2010) 18-25.

[96] H.-J. Fell, O. Krischer, Weg vom Öl-hin zu Erneuerbaren Energien, Solarzeitalter 2013 (2013) 86-90.

[97] Eurosolar, Eckpunkte für die Weiterentwicklung des EEG, Solarzeitalter 3 (2012) 3-8

[98] V. Hollain, Scheinheilige Debatte um das Erneurbare-Energien-Gesetz. Solarzeitalter 2 (2012) 12-13.

[99] I. Pontenagel, Das Grossprojekt EEG statt Desertec, Solarzeitalter 4 (2009) 8-11.

[100] H. Scheer, Die Sahara-Sonne: für wen und für was? Solarzeitalter 1 (2009) $1-2$.

[101] H. Scheer, Jenseits von Kohle und Atom, 2007.

[102] EEG, Konsolidierte Fassung der Begründung für den Vorrang Erneuerbaren Energien, Bundesgesetzblatt. 2004 I. S. 1918, Bonn, 2004

[103] EEG, Begründung zu dem Gesetz für den Vorrang Erneuerbarer Energien, German Federal Ministry for the Environment, Berlin, 2008.

[104] I. Pontenagel, Die neue energiepolitische Gemengelage, Solarzeitalter 2 (2009) 1-2.

[105] K. Scheffer, Vom Bioenergiedorf zur autonomen Solarenergie-Region, Solarzeitalter 4 (2008) 23-30

[106] H. Scheer, Ein rückwärtsgewandtes Energiekonzept, Berlin, 2009.

[107] P. Schmidt, J. Lilliestam, Reducing or fostering public opposition? A critical reflection on the neutrality of pan-European cost-benefit analysis in electricity transmission planning, Energy Res. Soc. Sci. 10 (2015) 114-122. http://dx.doi.org/10.1016/j.erss.2015.07.003. 